\title{
Anatomizing the Screen Presence of Disabled Characters in Hindi Feature Films
}

\author{
Shreelata Prasad ${ }^{1}$, Geeta Kashyap ${ }^{2}$ and Prof. M. Rabindranath ${ }^{3}$
}

\begin{abstract}
Cinema and society are mutually reflective, influence each other in both constructively as well as precarious manner. While the practices of society pilots the ideas of filmmaking, the society also mirrors the values of its movies in various ways. The concerns of physically disabled (differently abled) group of the society has also attracted the filmmakers throughout the world including many from Indian movie industry a.k.a. "Bollywood". Many mainstream Bollywood movies have depicted the experiences of differently-abled people either as a part of the plot or as the main subject of the story while exploring varied ways of fascination with the topic. This paper is an attempt to shed light on how Bollywood mainstream cinema incorporates the idea of disability in their movies, and what is the level of sensitivity when it deals with issues of disability? Whether the idea of disability has been romanticized or patronized in Bollywood movies? Whether $\mathrm{B}^{\prime}$ town uses the idea of disability just to garner commercial success or to communicate about the concerns of a disability type? Quality content analysis of Bollywood feature films dealing with some physical dis-ability has been done to fulfil the objectives of the paper.
\end{abstract}

Keywords: Bollywood, Disability, Disability-Communication, Film on Disability, Mainstream Cinema, Physical Disability.

\section{Introduction}

Cinema and society are mutually reflective, influence each other in both constructively as well as precarious manner. While the practices of society pilots the ideas of filmmaking, the society also mirrors the values of its movies in various ways.

We often recognize various cultures and nations across the world via the passage of our schema or memory of these places received through mediated information, especially on visual or better say on audio-visual platform (Mitra, 1999). Although the contribution of some inter-related social forces is inevitable in making our perceptions of others particularly which we are not directly encountered with, the role of mass media portrayals of the same is undoubtedly quite imperative in influencing our understanding about out-groups, specifically when presented on screen media such as films in very realistic ways (Ramasubramanian, 2005). Hence, film represents various ethnic and demographic group though sometimes with the patronisation of their screen images.

1,2 Research Scholars, Dept. of Journalism and Creative Writing, Central University of Himachal Pradesh, Dharamshala, Himachal Pradesh-176215

3 Dean, Dept. of Journalism and Mass Communication, Indira Gandhi National Tribal University, Amarkantak, Madhya Pradesh (India) - 484886

\section{Social Impact of Movies}

Given the fact that India has the highest, as of 2013, annual film output, followed by Nigeria a.k.a. Nollywood, United States a.k.a. Hollywood and China and thus boasts a large base of cinemaaudience, we can say that cinema is the most popular and most accessible of all media as well as art forms in India and has the power to influence Indian masses more than any other popular culture. Therefore, it is needed to understand how the country, its society, and its people are represented in the films produced in it. As a medium of mass communication, in India cinema has been seen and appreciated at different levels for serving different purposes, viz. it can be grasped as an art form, a source of entertainment, a social document as well as a social critique. Or, at some point cinema can serve as all of these and at the same point of time it can be a mirror of our society, showing the audience exactly how they function in their lives and what are their attitude about the subject being portrayed in it.

Like rollercoaster rides movies have the incredible power to entertain as well as to teach. A well-made film with a compelling narrative and well-crafted outreach plan would logically work as a catalyst on the stakeholders of the society viz. its audiences and change their minds, encouraging them to change their entrenched behaviours about the social issue(s) being depicted in it, and thus reenergize social movements (Barrett, et. al, 2008). 


\section{Portrayal of Disability on Screen}

As per the definition of the disable world 'Disability' is defined as a condition or function judged to be significantly impaired relative to the usual standard of an individual or group. The term is used to refer to individual functioning, including physical impairment, sensory impairment, cognitive impairment, intellectual impairment mental illness, and various types of chronic disease.

This may affect the body organs of an individual or it may be affecting person's participation in areas of life. There are three dimensions of the disability recognized by International Classification of Functioning, Disability and Health, known as ICF:

\section{Body Structure and function}

2. Activity (activity restrictions)

3. Participation (participation restrictions) (Disabled World, n.d.)

As per Oxford dictionary 'Disease' is defined as, "A disorder of structure or function in a human, animal, or plant, especially one that produces specific symptoms or that affects a specific location and is not simply a direct result of physical injury'.

Therefore, disability and disease cannot be used interchangeably. However, Disease may lead to disability, but disability is not a disease.

The way in which we can examine films dealing with disabilities as reflection of a society's attitude towards the subject is to study thoroughly the history of account when disabilities and films have had shared a common audience (Norden, 1994). While analysing society's transforming attitude towards disability with special reference to cinema, Morris (1991) explain:

Disability in film has become a metaphor for the message that the non-disabled writer wishes to get across in the same way that beauty is used. In doing this, movie makers draw on the prejudice, ignorance and fear that generally exist towards disabled people, knowing that to portray a character with humped back, with a missing leg, with facial scars, will evoke certain feelings with the audience. Unfortunately, the more disability is used as a metaphor for evil or just to induce a sense of unease, the more the cultural stereotype is confirmed.
Indian cinema, frequently criticized for stereotyping portrayal of love, emotion and violence, has also depicted stories on social themes remarkably, especially when one made attempts to highlight the uncommon diseases and disability. The concerns of physically/mentally disabled (differently abled) group of the society has also attracted the filmmakers throughout the world including many from Indian Hindi movie industry a.k.a. "Bollywood". Many mainstream Bollywood movies have depicted the experiences of differently-abled people, the largest minority in the world, either as a part of the plot or as the main subject of the story, but, while exploring varied ways of fascination with the topic. Filmmakers have often portray disabilities between the two extremes of human behavioural traits with pity, awe, humour, caricaturing, sympathy, and heroism at the one end while discernment, coping-up, aspirations and emotional swings at the other end (Mohapatra, 2012).

Martin F. Norden (1991) in his book, The Cinema of Isolation: A History of Physical Disability in the Movies, argued that makers of silver screen boast a general tendency to isolate disabled characters and this tendency comes in line of the way the disabled minority has been treated in the society for centuries. As cited by Norden, Andrew Grant and Frank Bowe have asserted, "Prior to the late 1960s and early 1970s, being disabled almost assured social, educational and occupational isolation." But, the latest manifestation of bringing disabled minorities out of the grip of stereotyping and special institutions and allowing them to experience life phases into the mainstream of society where they and the able-bodied people can learn from each other has destabilised the trend of isolation, but regrettably we have to say that it has done less to mitigate the filmmakers' tendency to portray disabled characters as isolated individuals. In Hollywood movies the people with disabilities have always been depicted dependent. Besides, there is variation in depicting these characters from stereotypical to influencing ones while showing their relations with the society. However, with the passage of time, the interference of science and technology in films brought new techniques and dimensions but it has moved from one stereotype to another stereotype.

Paul K Longmore (2003) in his article - Screening Stereotypes: Images of Disabled people in Television and Motion Pictures- indicates that a little has been changed in moviemakers' attitudes, as he says: 
The disabled person is excluded because of the fear and contempt of the nondisabled majority. Still, even when the handicapped character is presented sympathetically as a victim of bigotry, it remains clear that severe disability makes social integration impossible. While viewers are argued to pity such a character, we are let off the hook by being shown that disability or bias or both must forever ostracize severely disabled persons from society.

We often see that many diseases, in any social theme, are being portrayed in a manner where the sick character has either overcome it or die with a pang. However, disability with its various form has been shown in different characters and in different scenario such as where the character is suffering a disability type by birth or where disability occurred in later stage or age of the character.

In this paper, what follows is a brief contemplation of the very common screen images of people with physical, sensory, and developmental disabilities and some thoughts about their underlying social and psychological meaning. This paper exhausts a range of celluloid images or their significance to illuminate further the social and cultural attitudes and concerns movies reflect and express for differently-abled people and at what level of sensitivity. It also drives concerns about the idea of disability being used to add romanticism or patronization in the context of disabled protagonist or disabled nonprotagonist. Further, it is pertinent to shed light on the changing paradigm of characterization of disability on silver screen in the milieu of a new socio-political consciousness about disability, particularly among disabled people themselves.

\section{Portrayal of Disability in Hindi Cinema}

In Bollywood film industry, the idea of disability has been exploited in varied ways ever since the early era of Bombay talkies emerged. K. Sawhney (n.d.) notes that from Punishment, comedy, and dependency to heroism, disability has been portrayed in all forms of human actions and entertainment. According to him disability has been represented in the following traits of humankind:

\section{Disability as Punishment}

Although in an exaggerated fashion, disabilities often boast in to villainous characters, which reflects and reinforces three frequently acceptable prejudices against disabled people and those are: disability is a punishment for evil; disabled people are embittered by their "fate"; and disabled people resent the nondisabled and would, if they could, destroy them (Longmore, 2013).

Portrayal of disability in Hindi cinema has always been the central theme of all the skewness in a human biological system. In India, the disability had primarily introduced in Hindi Cinema either as a punishment or dependence. The 1936 film, Jeevan Naiya, written by Niranjan Pal was one of the earliest Hindi films that portrayed but as punishment. An approach to the idea of social justice, the film's lead character abandons his wife given her background from a family of dancers, and this mistreatment towards his better half subsequently leads him to meet an accident that left him blind, but later he was nursed back to health by the woman who later revealed to be his same devoted wife he left following the social taboo. In Bollywood, the idea of disability had been used as the severe punishment for a range of sins. For example, the wicked father-in-law is blinded in Aadmi (1968), in Kasam (1988), the chieftain of a village of criminals gets disabled in a police attack, in Jalte Badan (1973), Kiran Kumar, a drug addict, gets blinded, in Kashish (1972) the evil brother Asrani gets crippled for tormenting his Deaf sister and brother-in-law, also in Dhanwaan (1981), the rich atheist gets Rajesh Khanna is blinded for his arrogance and as a result unable to arrange a new pair of eyes for himself, but later on repenting and turning to God, he finally finds a benign donor. However, during this same era of showing disability as punishment, Gulzar made the first attempt to generate compassion to the inabilities of disabled people on screen by unfurling a basic discussion of sign language and independent living for the deaf and mute folks through his path-breaking film "Koshish" released in 1971.

\section{Disability as a comic punch}

Taking cinema as a general source of entertainment, it can be said that feature films has a fantastic disconnectedness from reality, especially in case of Indian Cinema. In the same pattern, the representation of disability has also been done in an unrealistic way in some Bollywood films. Disability has been exploited as comic interlude rather than a sensitive issue in many action or light entertainment movies. In movies such as Tom, Dick and Harry (2006) and PyareMohan (2006), the protagonists are characters with different disabilities, and their physical and sensory limitations as well as their interaction with each other and other able-bodied people have been used pull up comic entertainment for the audience. Some other movies in which 
physical and sensory inabilities have been well exploited to generate comic are Golmaal (2006), in which the character of Tushar Kapoor has oral disability and Paresh Rawal and his wife are blind, Mujhse Shadi Karogi (2004), where Kader Khan played the character of a person with shifting different disability every day, and Judaai (1997), in which Upasna Singh played a comic character who has speech disorder.

\section{Disability as an object of pity and dependence}

Pity and dependence has been the biggest stereotype or stigma associated with the portrayal of disability world of Hindi cinema. Rajashri Production's Dosti in 1964, Guzaarish 2010 and at latest Barfi! in 2010 are the best examples of central characters' dependency due to disability. Apart from this, there are many films in which supporting characters such as disabled parents and siblings as in Khamoshi (1996) and Tera Mera Sath Rahe (2001), respectively, are shown as dependent folks.

\section{Disability as heroism}

Some Bollywood film directors have also stretched their fantasies for disabled characters as heroes and super-heroes by moulding their inabilities into the different abilities. The examples of such films include 1998 thriller Dushman, in which the character of Sanjay Dutt, a blind veteran, fights the villainous character of Ashutosh Rana when he tries to rape the female protagonist played by Kajol. He uses his "sixth sense" to determine the culprit's position and movement. Similarly, in Aankhen (2002), the characters of Akshay Kumar, Paresh Rawal and Arjun Rampal despite being blind successfully accomplished a bank heist using their "sixth sense". Although these movies portray people with disabilities in a positive light, they also falsify the real being and capabilities of these people; instead of improving understanding for disabled, these films have breaks whatever scarcely available sensitivity society hold for them. As noted by Kalpana Nair (2015), Rustom Irani, an independent film-maker, guest columnist and more than $60 \%$ disabled wheelchair user, writes in his ten-part series for Mumbai Mirror called 'Mumbai On Wheels':

There are a couple of disability tropes that need to disappear from Bollywood....Please don't enhance the other senses and skills of disabled characters to superhuman levels because they lack a particular physical ability.

\section{Theoretical Framework}

\section{The Concept of Framing}

When it comes to study screen images in films, framing theory makes the base for the analysis. The concept of framing essentially involves selection and salience Entman (1993) refers to framing as essentially involving selection and salience. He describes framing as:

To select some aspects of perceived reality and make them more salient in a communicating text, in such a way as to promote a problem definition, causal interpretation, moral evaluation, and/or treatment recommendation for the item described.

While applying the concept of framing to film analysis, filmmakers dynamically involve in frame building by picking certain attributes and elements of the subject from reality, and then encapsulating these selected aspects through an issue and putting them on screen using cinematic techniques such as cameras, situational contexts, certain actors/actresses, language and scripts.

\section{Research questions}

RQ1: How a Bollywood mainstream cinema incorporates the idea of disability?

RQ2: Whether the idea of disability has been romanticised or patronized in Bollywood movies?

RQ3: Whether the level of sensitivity with which the disability has been dealt in both the cases when the character is protagonist or nonprotagonist varies?

RQ4: Whether B'town uses the idea of disability just to garner commercial success or to communicate about the concerns of a disability type?

\section{Methodology}

\section{Qualitative Content Analysis}

When it comes to study the portrayal of a certain group or issue on screen, qualitative content analysis is considered the best approach. According to Wimmer and Dominick (2013), content analysis is "a method of studying and analysing communication in a systematic, objective and quantitative manner for the purpose of measuring variable." They further elaborated that content analysis method is the best approach to study the screen images of a certain group. So, content analysis in the context of this study will help in analysing the purpose and the way disability has been represented in Bollywood cinema in the recent time frame of 2001-2015. 


\section{Sampling Units}

Bollywood feature films with disabled characters constitute the population for this study. Since there is a huge number of such movies available, the study is limited to the analysis of only such films which are produced during the time span year 2001-2015. While majority of such movies have disability as the central theme and thus, presented disabled protagonist or the central character(s), there is also a good number movie which portray disability through non-protagonist characters. Therefore, the stratified random sampling is being used to sort out the appropriate movies to study. Following this sampling method, all the movies with disabled characters, whether protagonist or non-protagonist, released during 2001-2015 were being divided into two strata [see table 1] - one includes movies in which the protagonist or central character is suffering a disability type and the other one includes such films in which disability condition is rested with the non-protagonist characters. Then, two films from each of these two strata picked randomly to analyse the screen images of disability. By stratifying movies in these two ways of disability portrayal, it was easy and fair to understand the way the idea of disability has been incorporated in recent Bollywood feature films, and also to disability has been dealt in both the cases when the character is protagonist or non-protagonist.

\section{Recording units:}

Protagonist or Non-protagonist

Box office - Box-office success of movies

\section{Context Units:}

- Type of disability: Physical, Sensory, and Developmental disabilities

- Age of the disabled character: Teenager, Adult, Mature adult, Elderly, Undetermined

- Genre of the film

- Character traits of the disabled person: Weak, Pity, Humour, Sympathy, Heroism, Comic, coping-up, Self-dependent, happy-golucky

- Subliminal context of the Character

Having worked according to the said sampling method, following Bollywood Hindi movies had been picked for analysis:

Movies with disabled protagonist: Koi... Mil Gaya and Barfi!

Movies with disabled non-protagonist: Tera Mera Saath Rahe and Golmaal

Table 1: Popular Bollywood Films Portraying

\begin{tabular}{|c|c|c|c|c|c|c|c|c|}
\hline Movies & \begin{tabular}{|} 
Protagonist \\
Vs. Non- \\
Protagonist
\end{tabular} & \begin{tabular}{|l} 
Physical \\
disability
\end{tabular} & $\begin{array}{c}\text { Mental } \\
\text { disability }\end{array}$ & $\begin{array}{l}\text { Disability } \\
\text { by Birth }\end{array}$ & $\begin{array}{l}\text { Disability } \\
\text { at later } \\
\text { stage }\end{array}$ & $\begin{array}{l}\text { Disability } \\
\text { cured } \\
\text { Yes/No/N/A }\end{array}$ & $\begin{array}{c}\text { Romantic/ Heroism/ } \\
\text { Emotional drama/ } \\
\text { Sympathetic base/ } \\
\text { Comedy }\end{array}$ & $\begin{array}{l}\text { Success in } \\
\text { terms of } \\
\text { earning }\end{array}$ \\
\hline $\begin{array}{l}\text { Tera Mera } \\
\text { Saath Rahen } \\
(2001)\end{array}$ & $\begin{array}{c}\text { Non- } \\
\text { protagonist }\end{array}$ & $x$ & $\checkmark$ & $\checkmark$ & $x$ & No & $\begin{array}{c}\text { Emotional } \\
\text { Drama/Romantic }\end{array}$ & $\begin{array}{l}\text { Rs. 5,65,30,000 } \\
\text { (Rs.56.53 } \\
\text { million) }\end{array}$ \\
\hline $\begin{array}{l}\text { Aankhen } \\
(2002)\end{array}$ & \begin{tabular}{|c|} 
Non- \\
protagonist
\end{tabular} & $\checkmark$ & $x$ & $\checkmark$ & $\checkmark$ & No & Heroism & $\begin{array}{c}\text { Rs.33,80,75,000 } \\
\text { (Rs.338.07 } \\
\text { million) }\end{array}$ \\
\hline $\begin{array}{l}\text { Koi Mil Gaya } \\
(2003)\end{array}$ & Protagonist & $x$ & $\checkmark$ & $\checkmark$ & $x$ & Yes & $\begin{array}{c}\text { Heroism and } \\
\text { Sympathetic base }\end{array}$ & $\begin{array}{c}\text { Rs.82,32,62,500 } \\
\text { (Rs.823.26 } \\
\text { million) }\end{array}$ \\
\hline Black (2005) & Protagonist & $\checkmark$ & $x$ & $\checkmark$ & $x$ & No & $\begin{array}{c}\text { Heroism/Emotional } \\
\text { drama }\end{array}$ & $\begin{array}{l}\text { Rs.65,21,00,000 } \\
\text { (Rs.652.10 } \\
\text { million) }\end{array}$ \\
\hline $\begin{array}{l}\text { Iqbal } \\
(2005)\end{array}$ & Protagonist & $\checkmark$ & $x$ & $\checkmark$ & $x$ & No & $\begin{array}{c}\text { Heroism/Emotional } \\
\text { drama }\end{array}$ & $\begin{array}{c}\text { Rs.5,60,68,750 } \\
\text { (Rs.56.06 } \\
\text { million) }\end{array}$ \\
\hline $\begin{array}{l}\text { Chup Chup k } \\
(2006)\end{array}$ & Protagonist & $\checkmark$ & $x$ & $\checkmark$ & $x$ & No & $\begin{array}{c}\text { Sympathetic } \\
\text { base/Comedy/Romantic }\end{array}$ & $\begin{array}{c}\text { Rs.25,58,00,000 } \\
\text { (Rs.255.80 } \\
\text { million) }\end{array}$ \\
\hline Fanaa (2006) & Protagonist & $\checkmark$ & $\bar{X}$ & $\checkmark$ & $\mathrm{X}$ & Yes & $\begin{array}{c}\text { Romantic/Emotional } \\
\text { drama }\end{array}$ & $\begin{array}{c}\text { Rs.1,05,48,00,000 } \\
\text { (Rs.1.05billion) }\end{array}$ \\
\hline $\begin{array}{l}\text { Tom Dick \& } \\
\text { Harry } \\
(2006)\end{array}$ & Protagonist & $\checkmark$ & $x$ & $\checkmark$ & $x$ & No & Comedy & $\begin{array}{c}\text { Rs.13,51,50,000 } \\
\text { (Rs.135.1 } \\
\text { million) }\end{array}$ \\
\hline $\begin{array}{l}\text { Omkara } \\
(2006)\end{array}$ & \begin{tabular}{|c|} 
Non- \\
protagonist
\end{tabular} & $\checkmark$ & $x$ & $\checkmark$ & $x$ & $\mathrm{~N} / \mathrm{A}$ & Romance \& Drama & $\begin{array}{l}\text { Rs. } 42,41,20,000 \\
\text { (Rs.424.12 } \\
\text { million) }\end{array}$ \\
\hline
\end{tabular}




\begin{tabular}{|c|c|c|c|c|c|c|c|c|}
\hline Movies & \begin{tabular}{|} 
Protagonist \\
Vs. Non- \\
Protagonist
\end{tabular} & $\begin{array}{l}\text { Physical } \\
\text { disability }\end{array}$ & $\begin{array}{c}\text { Mental } \\
\text { disability }\end{array}$ & $\begin{array}{l}\text { Disability } \\
\text { by Birth }\end{array}$ & $\begin{array}{c}\text { Disability } \\
\text { at later } \\
\text { stage }\end{array}$ & $\begin{array}{c}\text { Disability } \\
\text { cured } \\
\text { Yes/No/N/A }\end{array}$ & $\begin{array}{c}\text { Romantic/ Heroism/ } \\
\text { Emotional drama/ } \\
\text { Sympathetic base/ } \\
\text { Comedy }\end{array}$ & $\begin{array}{c}\text { Success in terms of } \\
\text { earning }\end{array}$ \\
\hline $\begin{array}{l}\text { Golmaal- } \\
\text { Returns } \\
(2008) \\
\end{array}$ & $\begin{array}{c}\text { Non- } \\
\text { protagonist }\end{array}$ & $\checkmark$ & $X$ & $\checkmark$ & $X$ & No & Comedy & $\begin{array}{c}\text { Rs.80,00,80,000 } \\
\text { (Rs.800.08 million) }\end{array}$ \\
\hline $\begin{array}{l}\text { Golmaal } 3 \\
(2010)\end{array}$ & \begin{tabular}{|c} 
Non- \\
protagonist
\end{tabular} & $\checkmark$ & $X$ & $\checkmark$ & $X$ & No & Comedy & $\begin{array}{c}\text { Rs.1,69,56,35,000 } \\
\text { (Rs.1.69 billion) }\end{array}$ \\
\hline $\begin{array}{l}\text { My Name } \\
\text { Is Khan } \\
(2010)\end{array}$ & Protagonist & $x$ & $\checkmark$ & $\checkmark$ & $X$ & $\mathrm{~N} / \mathrm{A}$ & $\begin{array}{l}\text { Romantic/Heroism/E } \\
\text { motional drama }\end{array}$ & $\begin{array}{l}\text { Rs.2,05,70,00,000 } \\
\text { (Rs.2.05 billion) }\end{array}$ \\
\hline $\begin{array}{l}\text { Guzaarish' } \\
(2010)\end{array}$ & Protagonist & $\checkmark$ & $X$ & $X$ & $\checkmark$ & $\mathrm{N} / \mathrm{A}$ & $\begin{array}{c}\text { Romantic/ Emotional } \\
\text { drama }\end{array}$ & $\begin{array}{c}\text { Rs.54,89,45,000 } \\
\text { (Rs.548.94 million) }\end{array}$ \\
\hline $\begin{array}{l}\text { Lafange } \\
\text { Parinde } \\
(2010) \\
\end{array}$ & Protagonist & $\checkmark$ & $X$ & $X$ & $\checkmark$ & No & $\begin{array}{c}\text { Romantic/Emotional } \\
\text { drama }\end{array}$ & $\begin{array}{c}\text { Rs.31,99,25,000 } \\
\text { (Rs.319.92 million) }\end{array}$ \\
\hline $\begin{array}{l}\text { Barfi! } \\
(2012)\end{array}$ & Protagonist & $\checkmark$ & $\checkmark$ & $\checkmark$ & $X$ & No & $\begin{array}{c}\text { Romantic/Emotional } \\
\text { drama }\end{array}$ & $\begin{array}{c}\text { Rs.1,74,73,80,000 } \\
\text { (Rs.1.74 billion) }\end{array}$ \\
\hline
\end{tabular}

*Box office earning source: Box Office India (BOI)

\section{Analyses \& Discussions}

Film: Koi... Mil Gaya

\section{Disabled Character: Protagonist}

\section{Age of the disabled character: Adult}

\section{Genre of the film: Science fiction and Romance}

Character traits of the disabled person: Pity, Sympathy \& coping-up

Largely inspired by Steven Spielberg's 'E.T. the Extra-Terrestrial', Rakesh Roshan's 'Koi...Mil Gaya' was a mainstream science fiction movie, starring Hrithik Roshan and Preity Zinta. 'Koi...Mil Gaya' was the story of a disabled boy Rohit, played by Hrithik Roshan, whose life changes when he comes across an extra-terrestrial. Released in the year 2003, the movie has its theme revolves around heroism and sympathetic base. The film received highly positive critical reviews and was declared a "Blockbuster" by Indian Box office with a total earning of ₹1.03 billion.

The character of Rohit, a child-man, is mentally disabled due to a brain injury he received in an accident while still being a foetus. He is survived by his mother and lives a middle-class life. He faces ridicule and torment at every phase of his life. But, one day with the help of his lone companion Nisha, played by Preity Zeinta, Rohit managed to contact and call, though by fault, the Aliens through his demised scientist father's computer, and this incident led an extraterrestrial left behind on earth. Ever since Rohit become friend with that alien, his life has been changed drastically and dramatically, given the silver screen requirement of dramatized twist. The alien, named Jaadoo by Rohit, bestowed powers on Rohit that made him to behave and act normal as of his age; his Intelligent Quotient increased; and he physically become stronger. By the virtue of his new powers, the protagonist becomes a hero among his friends and people around.

In this movie the idea of disability is well utilized to give momentum to the heroism of the protagonist rather than to aware and sensitize the audience, a part of the society, about the type of disability the protagonist is suffering from. At one point it can be said that the idea of disability has been used to make the audience to patronize the mentally challenged protagonist who had been mocked by his peers, but at the second point the disability condition of Rohit helped romanticize his character when he became normal with the power bestowed on him by his extra-terrestrial friend. Since the protagonist is differently-abled in this film, the director has dealt with the disability condition with high sensitivity as in scenes where his school teacher insults in the classroom when he couldn't give the answer to a simple question, and where his ill-minded peers bullied him and broke his scooter, and he couldn't fight back.

Subliminal context of the Character: The character of Rohit unconsciously gives a message that until you are a disabled character there is no acceptance in the society. In the last scene of the 
movie when extra-territorial friend was moved back a sad atmosphere was created because Rohit superpowers has also been gone back with him. But then suddenly, he got the power back again as a gift from his friend. And then there is a happy-ending. Such things are not possible in real-life. For this film, it can be said that the idea of disability has been used to add peculiarity as well as popularity to the protagonist, and subsequently, to garner commercial success rather than to make audience or society sympathise and empathise people with disability.

\section{Film: Barfi!}

\section{Disabled Character: Protagonist}

\section{Age of the disabled character: Adult}

\section{Genre of the film: Comedy-drama \& Romance}

Character traits of the disabled person: Selfdependent, happy-go-lucky, heroism

Released in 2012, Barfi! is a Bollywood film directed by Anurag Basu who explores an intriguing relationship between a deaf and mute person, an autistic person and a normal person. This film is a comedy-romance-drama with disabled protagonists - a deaf and dumb man, Murphy (Ranbir Kapoor) whom everyone calls Barfi, and Jhilmil (Priyanka Chopra), an autistic grown up girl and a childhood friend of Barfi. Received as a path-breaking film that has changed the Hindi Film Industry's perception about the abilities of the disabled characters, the film Barfi! garnered a huge commercial success at box office and became one of the highest-grossing Bollywood films of 2012 in India with a gross 24.8 Million of revenue.

The film Barfi! revolves around a boy named Murphy, popular as Barfi and Jhilmil, an autistic character in the film who is a childhood friend of Barfi. Although, Barfi can neither speak nor listen, a deaf and mute by birth, he is quite an attention grabber with always up to a prank in his mind. Barfi lives his life with full enthusiasm, without an inch of melancholy of being a disabled person and works around his dis-abilities with always carrying a smile on his face. With his spirits always high enough, he falls in love with Shruti (Illeana D'Cruz), a physically normal girl unlike him, and she too starts loving him for his happy go lucky attitude for life but gives up to the societal pressure of disabled-nondisabled as well as rich-poor gap they had and ends up marrying someone else. Then enters Jhilmil in Barfi's life. With his utter zest for life, Barfi even helped Jhilmil to meet life beyond her disabilities. However, some audiences fail to understand the character of Jhilmil, but within the movie plotline,
Barfi instantly finds a bond with the girl (Pal, 2012).

Barfi! is a film which pulls the audience into the world of the disabled without carrying the weight of pity. However, the focus of this film is not on the portrayal of associated predicaments of disabled characters, rather its more about enjoying life, giving happiness, feeling love, as quoted by the actor Ranbir Kapoor (PTI, 2012). Despite being a deaf and mute person, Barfi never stops experiencing the joys of life.

Subliminal context of the Character: Since there is negligible scene where awe and pity has shown for the disabilities of protagonists, it can be said that the idea of disability has been used to romanticize the plotline of the movie. The disability conditions has been dealt with less sensitivity. There is no scene where the protagonists have been mocked for them disabilities, rather the character Barfi plays pranks with others, which obviously bestows him with power to take life easily. Along-with it, it has shown that the relationships for disabled character with non-disabled person is difficult. However, in the movie it was more rich-poor gap than disabled and non-disabled gap. The ease with which disabled protagonists live in this movie, it can be said that the disability conditions has been exploited just to add novelty along with compassion to the protagonists and thus to garner commercial success for the movie rather than to communicate about the concerns for deaf-andmute and autistic people.

\section{Film: Tera Mera Saath Rahe}

\section{Disabled Character: Non-Protagonist}

Age of the disabled character: Teenager

Genre of the film: Drama commercial

Character traits of the disabled person: Pity, Sympathy \& coping-up

Based on emotional drama, the movie showcased the relation of two brothers one mentally and physically disabled. Raj Dixit (Ajay Devgan) lives with his 14-year-old brother Rahul (Dushyant), who is a victim of Cerebral Palsy, a neurological disorder that prevents proper development of child's brain. Raj understand all his needs and emotions too and Rahul is totally dependent on him. Rahul is playing football on beach and Raj just feels happy watching him in the beginning evening shot of the movie. Raj Dixit is a hardworking man and along with office he takes care of his brother very well. In one scene Rahul got injured while playing and he was taken to hospital and there a ward boy calls him mental. 
Then Raj beats him up and make ward boy to apologise for the same. This was actually a reality of society and somewhere there was sensitivity shown while dealing with the subject.

The character was also shown involved with social activities. The movie gradually shifted from Rahul life to Raj life where love-triangle intersects their life. Suman (Namarta Shirondkar) likes Raj but then Raj is introduced to Madhuri (Sonali Bendre) by Mr. Khanna. Madhuri enters into the life of Rahul turning into his good friend. Madhuri later suggested to send Rahul to school where he can be educated also. Raj was reluctant and on insisting her he agrees to send him to school for his brother welfare only. Rahul was depressed after listening this news and became violent. The story develops, and Raj realises that it is not Rahul who is dependent on him rather he is dependent on him. In realization, he approaches Madhuri and refuses her to marry. He further goes to school and bring Rahul back home. Unlike common Bollywood films, there is no as such happy ending but Mahesh Manjrekar (director) leaves the ending open for interpretation situation. Madhuri realises her selfishness and apologies for the same to Raj as well as Rahul.

Subliminal context of the Character: The movie gives a positive message that disabled person are no different community and they are part of our society only. Alienating them from society will turn them into more violent than before. The interlude of dance and songs were more than required which makes the movie losing its plot in the mid of the film. Box-office results were really souring for this movie. And this also raises question wherever the disability issues are dealt with sensitivity they are not much like by the audiences? However, the emotional music, dance, drama all were part of this movie. Movie has depicted the woes of disabled people but commercially it was not much successful (see table 1).

\section{Film: Golmaal}

\section{Disabled Character: Non-Protagonist}

\section{Age of the disabled character: Adult}

\section{Genre of the film: Comedy}

\section{Character traits of the disabled person: comic}

Golmaal trilogy has role played by Tushaar Kapoor of being a mute guy. The character was non-protagonist in the film. In all the series of the film, he was shown making fun of him by his peers. There was a dialogue in one the series "Tera speaker phata hua hai (your vocal cord is bursted out)". In Golmaal Returns in of the scene
Tushar Kapoor was flirting with a beautiful girl. His friends noticed it and they start making disturbances. However, the girl still kept on meeting him. Tushaar Kapoor used his friend's voice for good impression. But all friends broke into laughter when they came to know that the girl was deaf. They make this point as a laughing point in the movie. In three of the Golmaal series the story revolved around four friends and the trouble created through the situation. The film is all comedy and fun. The Guy Lucky (Tushar Kapoor) remained mute in three of the series and he was made fun of that disability in three of the series.

Subliminal context of the Character: The movie seems giving only one message that there will always be made fun of one's disability. The other characters tried to generate comedy because of that disability. There was no sensitivity shown while dealing the character in the film. The idea behind including such character in the movie is not clear. What was the need to do so? In real-life such conditions are not true. They are not acceptable as such in the society commonly. Generally, people with disability are not happygo-lucky or cool as they are shown on screen. In this film, disability was used to create fun and it was commercially very successful (see table 1 ).

\section{Conclusion}

In Bollywood mainstream movies, the protagonists are those who can represent ideal aspects, something that everyone can connect to. A protagonist is a person with heroic traits who cannot be desexualized, cannot be incomplete, cannot be someone to be made fun of, and cannot be dependent. The disabled bodies thus have conventionally fulfilled either supporting character roles, or else if they are the central characters or protagonists, they must become an object of tragedy or their senses and skills would be stretched beyond reality, in an exaggerated fashion.

The disabled character is somewhat sensitive and sensible when they are protagonist in a movie but in non-protagonist role, their woes are scarcely shown; generally, a mockery is created or fun of their disability is made. The depth with which the disability conditions has been dealt in Bollywood cinema varies based on the role of the disabled character as protagonist or non-protagonist. Sometimes it is puzzling why disabled characters were used in non-protagonist roles as movie are mostly fiction-based.

The portrayal of disability in early eras of Bollywood was social with high level of patronisation but the new trend of Hindi cinema 
has gone beyond stereotyping the disability conditions like in the film Barfi! that is the manifestation of Bollywood's concern of pulling up the abilities of disabled, though in exaggerated fashion, to add romanticism to the theme to engage more audience. The $\mathrm{B}^{\prime}$ town film makers also uses disabled characters to pull up comic interludes, which is way too far from a real situation.

Films in which the disabled character is protagonist and being portrayed in exaggerated fashion with all the heroic activities such as 'Koi...Mil Gaya' and Barfi! are higher grosser. On the other hand, films in which the nonprotagonist character(s) are shown with a disability conditions such as Tera Mera Saath Rahen and Golmaal sequels are usually make lesser box office revenue. However, it is also being noted that the movie, like Iqbal, in which the disabled character is a protagonist but as a dependent folk, grossed poorly at box office, as per the table 1.

The movies dealing the disability conditions with less sensitivity are commercially more successful. In fact, filmmakers consider the issue of physical disability as a politically charged commodity that can make audiences to 'buy' it.

\section{References}

Barrett, D. \& Leddy, S. (2008). Assessing Creative Media's Social Impact. The Fledging Fund. Retrieved November 27, 2016 from http:/ / www.thefledglingfund.org

Box Office India. Retrieved December 6, 2016 from www.boxofficeindia.com

Disabled World. (n.d.). Disability: Definition, Types and Models. Retrieved from https://www.disabledworld.com/disability/types/

Entman, R. M. (1993). Framing: Toward clarification of a fractured paradigm. Journal of Communication, 43(4), 51-58.

Longmore, P. K. (2003). Screening Stereotypes: Images of Disabled people in Television and Motion Pictures. Why I burned my book and other essays on disability (pp.131-146). Philadelphia: Temple University Press.

Mitra, A. (1999). India through the Western lens: Creating national images in film. Thousand Oaks, CA: Sage Publications.

Mohapatra, A. (2012). Portrayal of Disability in Hindi Cinema: A Study of Emerging Trends of Differently-abled. Asian Journal of Multidimensional Research.

Morris J. (1991). Pride against Prejudice: Transforming Attitudes to Disability, Celebrating the Difference. London: The Women's Press

Nair, K. (2015). Getting Real on Reel with Disability. The Times of India.

Norden, M. F. (1994). The cinema of isolation: A history of physical disability in the movies. Rutgers University Press.

Pal, J. (2012, September 13). Will Barfi! change the way Bollywood treats disability? First Post. Retrieved December 8, 2016 from http:/ / www.firstpost.com/bollywood/wil 1-barfi-change-the-way-bollywood-treatsdisability-453938.html

PTI. (2012, July 3). Do not associate 'Barfi' with disability, says Ranbir. The Times of India. Retrieved December 16, 2016 from http:/ / timesofindia.indiatimes.com/entert ainment/hindi/bollywood/news/Do-notassociate-Barfi-with-disability-saysRanbir/articleshow/14635687.cms

Ramasubramanian, S. (2005). A Content Analysis of the Portrayal of India in Films Produced in the West. The Howard journal of communications, 16(4), 243-265.

Sawhney, K. Tracing the portrayal of disability in Indian cinema. Retrieved December 20, 2016from http:/ / stanford.edu/ kartiks2/disabilityIn Bollywood.pdf.

Wimmer, R. D., \& Dominick, J. R. (2013). Mass media research. Cengage learning.

Websites:

www.boxofficeindia.com. 